Pembelajaran Kolaboratif Sekolah....(Ignasius Heri S.W., Ignatius Putera S., Antonius Singgih S.)

\title{
PEMBELAJARAN KOLABORATIF SEKOLAH DASAR MENGGUNAKAN MODEL VYGOTSKY
}

\author{
Oleh: Ignasius Heri Satrya Wangsa, Ignatius Putera Setiahati, \\ Antonius Singgih Setiawan \\ Email:ig_heri@ukmc.ac.id \\ (Universitas Katolik Musi Charitas Palembang)
}

\begin{abstract}
Abstrak
Aspek sosial menempatkan manusia yang hadir dan berinteraksi satu dengan lainnya. Dalam konteks pendidikan, ruang kelas menjadi sumber daya dimana model pembelajaran sosial diterapkan dengan melibatkan siswa untuk berinteraksi mengembangkan ketrampilan2 sosial mereka sekaligus mengelola kerjasama kolaboratif. Prosedur analisa naratif digunakan Peneliti untuk mendeskripsikan penerapan model pembelajaran sosial Vygotsky (Vygotsky, 1962; Gindis, 1999; Burkhalter, 1995; Totten, Sills, Digby \& Russ, 1991) dengan menggunakan lima domain yang memiliki relevansi terhadap pembelajaran kolaboratif sekolah dasar (Damon \& Phelps, 1989; Dillenbourg, 1999). Lima domain tersebut masing-masing adalah intervensi (intervention), pertukaran (exchange), ide (idea), peran (role), dan partisipasi (participation). Penelitian konseptual ini diharapkan dapat memberi sumbangan dalam literatur pembelajaran kolaboratif sekolah dasar.
\end{abstract}

Kata Kunci: Pembelajaran Kolaboratif, Model Vygotsky

\section{COLLABORATIVE LEARNING IN PRIMARY SCHOOL USING VYGOTSKY MODEL}

\begin{abstract}
The social aspect of human life has placed the essential presence of man employing his faculties in an interactive learning environment. In the educational context, classroom has become potential resource in which social learning model could be adopted while the students could improve their social skills within the framework of collaborative works. Procedure for narrative analysis is used to describe the adoption of Vygotsky social learning model (Vygotsky, 1962; Gindis, 1999; Burkhalter, 1995; Totten, Sills, Digby \& Russ, 1991). Five domains within the essence of Vygotsky model are employed to discuss collaborative learning at the elementary school (Damon \& Phelps, 1989; Dillenbourg, 1999). They are intervention, exchange, idea, role and participation. This conceptual research aims at contributing towards theoretical insights on collaborative learning at the elementary school.
\end{abstract}

Keywords: Collaborative Learning, Vygotsky Model 


\section{A. PENDAHULUAN}

Kolaborasi pembelajaran menjadi kata kunci dimana siswa difasilitasi oleh guru untuk saling bekerjasama dalam sebuah tugas kelompok baik di dalam ruangan kelas maupun di luar ruangan kelas. Model pembelajaran ini mengadopsi esensi pembelajaran yang dikemukakan oleh Vygotsky.

Model pembelajaran Vygotsky muncul sekaligus mengakhiri dominasi teori pembelajaran Piaget yang menekankan pada aspek biologi manusia, yakni pembelajaran dalam aspek "naluriah" manusiawi. Kapasitas pembelajaran seseorang akan tercapai dengan sendirinya seiring dengan pertambahan usia biologis. Secara biologis manusia memiliki mekanisme tertentu, dengan mengikuti pertambahan kedewasaan seseorang, yang mempengaruhi kapasitas pembelajarannya.

Model ini memberi perhatian kepada kehadiran individu lain dalam sebuah ruang pembelajaran. Kehadiran individu lain ini tidak sekedar menjadi "kepanjangan tangan" atau sarana bagi individu pembelajar untuk memenuhi keingintahuannya, melainkan kehadiran yang melengkapi (complementary). Kehadiran melengkapi (complementary) menempatkan sekelompok individu saling berinteraksi, berkolaborasi dan melengkapi satu dengan yang lain melalui berbagai bentuk kegiatan dalam sebuah ruang pembelajaran.

Relasi sosial dalam konteks pembelajaran mampu menciptakan "gap perbedaan" yang menjadi sarana dimana rasa keingintahuan (curiosity) muncul dan proses pembelajaran dioperasionalisasikan. Belajar pada dasarnya merupakan upaya untuk memenuhi rasa keingintahuan. Ini artinya, model pembelajaran sosial mampu menumbuhkan daya yang menggerakkan seseorang untuk menemukan sesuatu yang baru.

Dalam penerapan strategi pembelajaran kolaboratif, sebagai salah satu bagian dalam penerapan pembelajaran sosial di ruang kelas, diperlukan pemahaman yang komprehensif. Alasan ini didasari oleh pertimbangan gap perbedaan. Individu memiliki kapasitas partisipasi dan keterlibatan yang berbeda dalam pembelajaran kolaboratif. Ini seringkali ditempatkan sebagai sebuah kelemahan bahkan ancaman bagi kesuksesan pembelajaran. 
Ketika anak saling beradu pendapat maka seringkali yang terjadi adalah intervensi orang dewasa agar supaya perbedaan pendapat itu dihilangkan. Anak diupayakan untuk lebih baik berdamai daripada berbeda pendapat. Ini menjadi semacam penyeragaman (uniformity) yang bertolak belakang dengan hakikat manusia yang berbeda satu dengan lainnya. Ruang pembelajaran menerapkan model pembelajaran kolaboratif, bertujuan mengembalikan esensi sosial siswa melalui kegiatan berbasis kelompok.

Artikel ini menyajikan tinjauan konseptual untuk melihat penerapan model Vygotsky dalam pembelajaran kolaboratif di sekolah dasar. Gindis (1999) menyatakan apa yang dikemukakan Vygotsky sebagai revolusioner karena mampu mengalihkan pemahaman perilaku manusia yang sebelumnya bersifat biologis kepada aktivitas manusia yang dapat dijelaskan secara sosial-budaya. Terdapat jalur penghubung antara proses sosial-budaya yang terjadi dalam masyarakat dan proses mental yang terjadi dalam diri individu.

Keberhasilannya adalah mengembangkan sebuah pendekatan yang menghubungkan proses sosial dan mental serta menjelaskan mekanisme penting sosialisasi dan perkembangan manusia. Ini kontras dengan teori yang dikemukakan Piaget dimana proses pematangan menentukan kemampuan kognitif anak sekaligus kemampuan belajarnya. Pembelajaran mengikuti tingkat kedewasaan individu. Menurut Vygotsky pembelajaran adalah proses berbagibergabung (shared-joint process) dikondisikan dalam sebuah konteks sosial. "...learning as a shared-joint process in a responsive social context"

Burkhalter (1995) mengemukakan tentang penerapan kurikulum menggunakan model Vygotsky untuk mengajar Menulis Persuasif di sekolah dasar. Dikatakan bahwa umumnya kurikulum sekolah dasar dibuat menurut model pengembangan kognitif Piaget. Menurut Piaget anak-anak sebelum mencapai usia 11 tahun tidak mampu mengerjakan tugas yang membutuhkan pemikiran formaloperasional (dalam Inhelder \& Piaget), antara lain ketrampilan formulasi, analisa, dan melakukan sintesisasi nalar. Bagi Vygotsky ini berbeda. Menurutnya anakanak sebenarnya mampu memperoleh ketrampilan kognitif di luar yang dapat 
dibayangkan oleh mereka ketika ketrampilan diukur dengan menggunakan tes eksperimen (Freedman \& Pringle, 1984 dalam Burkhalter, 1995).

Ditambahkan pula bahwa hal itu memungkinkan terjadi dengan keterlibatan orang dewasa dan teman-teman sebaya dalam proses pembelajaran. Anak-anak perlu dimotivasi atau, menurut bahasa Vygotsky, di "stimulasi” dalam proses pembelajarannya melalui sederetan tujuan dengan tingkatan kesulitan yang berjenjang. Anak yang tidak dihadapkan dalam tantangan seperti ini akan gagal untuk mencapai tingkatan pikiran yang lebih tinggi, ataupun bahkan, terjadi penundaan yang tidak seharusnya. Vygotsky mengatakannya sebagai “penundaan yang sia2" (Vygotsky, 1962).

Konsep pembelajaran kolaboratif, termasuk di dalamnya berupa kegiatan pembentukan kelompok dan siswa yang berpasangan satu dengan lainnya, bertujuan untuk mencapai tujuan akademik. Siswa mengikuti instruksi untuk melakukan berbagai macam tingkatan kegiatan, bekerja sama dalam kelompok kecil untuk tujuan yang sama. Siswa juga dikondisikan bertanggungjawab atas keberhasilan pembelajaran rekan-rekannya maupun dirinya sendiri. Mereka dapat saling membantu satu sama lain dalam meraih kesuksesan pembelajaran.

Konsep pembelajaran kolaboratif melibatkan sekelompok individu yang terikat dalam interaksi kerjasama (cooperation). Dalam konteks pembelajaran ruang kelas Johnson \& Johnson (1986) menyebut sebagai pembelajaran kooperatif, yakni pembelajaran yang dibagikan (shared learning). Siswa memiliki kesempatan untuk terlibat dalam diskusi, juga kesempatan untuk memegang tanggung jawab bagi kesuksesan proses pembelajarannya, sekaligus mengantarnya kepada pemikir kritis (Totten, Sills, Digby \& Russ, 1991).

Ketika pembelajaran terjadi dalam ruang kelas yang berisi beberapa individu, dan individu tersebut melakukan interaksi satu dengan lainnya dalam sebuah kegiatan pembelajaran, maka konsepsi pembelajaran sosial terbentuk. Ruang kelas menjadi sebuah "masyarakat mini", terdiri dari beberapa anggota "masyarakat" yang berelasi satu dengan yang lain. Melalui pemahaman ini muncul pengertian kelompok. 
Pembelajaran Kolaboratif Sekolah....(Ignasius Heri S.W., Ignatius Putera S., Antonius Singgih S.)

Pengertian kelompok dalam kerja kelompok pada umumnya dibagi menjadi tiga tipe, yaitu: tutorial teman sebaya, pembelajaran ko-operatif dan pembelajaran kolaboratif. Perubahan variabel didalamya ditentukan oleh meningkatnya tingkat keseimbangan dan keterikatan transaktif antara siswa (Damon \& Phelps, 1989).

Pembelajaran ko-operatif dan kolaboratif dibedakan dengan tutorial sebaya dalam "kepesertaannya" yang lebih bersifat horizontal daripada vertikal yakni dalam pengetahuan dan "kepakaran" dari siswa-siswa dalam sebuah kelompok; serta dalam diskusi dan pertukaran informasi dan ide antara para siswa sebagai sebuah mekanisme utama untuk mencapai pertumbuhan (Dillenbourg, 1999).

Pembelajaran ko-operatif menuntut sebuah program aktivitas yang sangat terstruktur dan variatif. Pembelajaran model ini memerlukan metode jigsaw dimana para siswa masing-masing memiliki tanggungjawab individual yang siap dibagikan kepada anggota lainnya dalam sebuah kelompok (Cohen, 1994). Sebaliknya, pembelajaran kolaboratif menggunakan tugas-tugas yang berbasis pada inisiatif diri sendiri serta berpusat pada aktivitas gabungan, yang secara khusus melibatkan tujuan jelas bagi tercapainya kesepahaman (shared understanding), yakni ketika pembelajar yang lebih senior terlibat di dalamnya (Summers, 2006).

\section{B. METODOLOGI PENELITIAN}

Prinsip umum analisa data kualitatif adalah membuat keseluruhan data, analisis dan interpretasi menjadi lebih sistematis dan dapat dipahami. Ini disebabkan karena data tidak selalu secara eksplisit dapat mengungkapkan sebuah arti (Blair, 2015:14). Dalam penelitian ini, proses yang dilakukan didasari atas pertanyaan "Bagaimana penerapan pembelajaran kolaboratif dalam konteks sekolah dasar?" dengan merasionalisasikan keterkaitannya terhadap lima domain dalam model pembelajaran Vygotsky (Vygotsky, 1962; Gindis, 1999; Burkhalter, 1995; Damon \& Phelps, 1989; Dillenbourg, 1999; Totten, Sills, Digby \& Russ, 1991). 
Domain-1 (Intervensi)._Perkembangan kapasitas pembelajaran ditentukan oleh kehadiran fasilitator untuk mengintervensi gap zona perkembangan potensial (Zone of Proximal Development) yang menghubungkan "apa yang telah diketahui" (actual development) dengan "apa yang hendak diketahui" (potential development)

Domain-2 (Pertukaran)_Perkembangan kapasitas pembelajaran berasal dari keterbukaan untuk berbagi dalam relasi interaktif pertukaran (exchange) "memberi-menerima". Kehadiran individu satu dengan yang lain ketika dikondisikan dalam relasi interaktif maka akan muncul pertukaran (exchange). Pertukaran memiliki obyek dan konsekuensi.

Domain-3 (Ide) Perkembangan kapasitas pembelajaran berasal dari keterbukaan terhadap pertukaran ide (exchange of idea). Pertukaran ide membuka jalan komunikasi dua arah. Ini adalah pola kolaboratif melibatkan kelompok individu untuk berbagi ide dan gagasan dimana mereka saling melengkapi.

Domain-4 (Peran) Perkembangan kapasitas pembelajaran berasal dari keterbukaan terhadap pertukaran peran (exchange of role). Pembelajaran sosial menciptakan atribusi peran ganda sebagai pencipta ide (idea creator) dan penyerap ide (idea acceptor), melibatkan tindakan untuk menginisiasi ide dan melengkapi ide. Inisiasi ide berasal dari setiap inisiatif untuk mengemukakan pendapat, sedangkan tindakan melengkapi ide berasal dari setiap upaya mendengar dan menerima pendapat dari orang lain.

Domain-5 (Partisipasi) Perkembangan kapasitas pembelajaran berasal dari keterbukaan terhadap pertukaran partisipasi (exchange of participation). Pembelajaran sosial menuntut partisipasi dari setiap individu. Partisipasi sebagai sebuah nilai merupakan dorongan keterlibatan individu dalam ruang pembelajaran sosial.

Untuk tujuan tersebut dalam penelitian dilakukan analisis data kualitatif terhadap lima partisipan, yakni para tenaga pendidik dari berbagai sekolah dasar dalam naungan Yayasan Pendidikan "X" di Palembang. Peneliti menggunakan metode interview terstruktur dimana partisipan diminta menyampaikan pendapat melalui jawaban atas pertanyaan panduan (guided questions) sebagai berikut: (1) 
Pembelajaran Kolaboratif Sekolah....(Ignasius Heri S.W., Ignatius Putera S., Antonius Singgih S.)

Bagaimana penerapan strategi pembelajaran dimana siswa bekerjasama dengan siswa yang lain misalnya dalam tugas kelompok yang dikerjakan di kelas baik tugas yang sifatnya tertulis maupun lisan?; (2) Bagaimana para siswa bisa bekerjasama satu dengan yang lain?; (3) Bagaimana para siswa merasa senang dan antusias dengan model pembelajaran tersebut?; (4) Bagaimana para siswa mengalami kendala?; (5) Bagaimana peran guru dalam merespon kendala tersebut?; (6) Bagaimana guru menilai efektivitas model pembelajaran tersebut?; (7) Apakah guru punya model pembelajaran lain yang dianggap lebih efektif daripada model pembelajaran sosial?

Jawaban dari pertanyaan panduan tersebut disampaikan secara lisan dan direkam. Peneliti kemudian membuat transkrip rekaman suara. Transkrip tersebut merupakan narasi yang kemudian diidentifikasi dengan menggunakan proses analisa naratif. Identifikasi diperlukan untuk menemukan kode dan kategori. Kode dan kategori kemudian dihubungkan sekaligus dirasionalisasikan dengan pemahaman mengenai pembelajaran kolaboratif dan teori pembelajaran sosial Vygotsky. Rasionalisasi ini diarahkan untuk mendeskripsikan penerapan pembelajaran kolaboratif sekolah dasar dengan menggunakan model Vygotsky.

\section{HASIL PENELITIAN DAN PEMBAHASAN}

1) Partisipan-1: Ibu "X"

Mengajar kelas 1. Merasakan perbedaan pengajaran kelas bawah - kelas atas. Pemutaran video. Anak-anak akan lebih berkonsentrasi. Melalui LCD. Biasanya dengan cara ceramah. Mendengarkan cerita. Metode demonstrasi, dengan contoh-contoh benda yang kongkrit. Anak kelas 1 masih sulit untuk membayangkan. Mengatasi anak kelas 1. Yang baru masuk masih sulit untuk membaca dan menulis. Untuk mengatasinya saya meluangkan waktu setelah les selama 30 menit untuk mengajar mereka. Tulisan tegak bersambung. Saya akan memegang tangan si anak untuk menulis tulisan bersambung. Setiap hari selalu komunikasi dengan orang tua. Mengikuti perkembangan seperti teman2 yang lain. Kode: kelas bawah - kelas atas, contoh benda yang kongkrit, memegang tangan Kategori: pembagian, intervensi 
2) Partisipan-2: Ibu "Y"

Tahun lalu mengajar kelas 2. Kesulitan untuk menerapkan modelnya. Waktu tersita untuk mengatur anak2. Strategi pembelajaran cooperative learning diskusi kelompok. Membagi materi, membagi kelompok berdasarkan kemampuan sedang, rendah, tinggi. Pembagian laki-laki - perempuan supaya sosialnya bagus. Mereka bekerja sama dengan baik. Tiap kelompok 1 ketua. Mereka sendiri yang menentukan.

Ada kendala tentang waktu dan anaknya yang sulit diatur. Kebanyakan mereka senang. Senang belajar bersama teman-temannya. Suasana hidup, tidak monoton. Kendalanya adalah waktu dan anak. Ada anak yang kurang aktif. Untuk penilaian model pembelajarannya. Saya senang dengan model pembelajaran seperti itu. Ada anak yang aktif dan tidak aktif. Penilaiannya bagaimana? Saya beri nilai yang sama. Kalau 90 ya semua. Penerapan model-model pembelajaran lainnya. Kalau nanti saya mengajar kelas tinggi. Saya pengen menggunakan model-model pembelajaran lainnya.

Kategori: pembagian, partisipasi, intervensi

3) Partisipan-3: Ibu "Z" Kode: waktu tersita, membagi kelompok, pembagian laki-laki - perempuan, mereka sendiri yang menentukan

Menurut saya dalam pembelajaran di dalam kelas. Strategi pembelajaran mengikuti perkembangan jaman strategi student-centered learning. Beberapa mt pelajaran yg mudah PPKN, Bhs Indonesia, SPDP. Utk kelas 3 mudah. Dibagi jadi beberapa kelompok. Pertanyaan yang saya ajukan. Siapa cepat. Jawaban tepat. Kriteria yang cepat, tepat. Kendala dalamm 1 kelompok tidak semua. Matematika dalam 1 kelompok hanya ada beberapa yang mampu. Saingannya sangat bagus. Kemampuan standar kebawah sulit mengikuti. Ya masuk dalam kelompok saja. Model pembelajaran sangat umum. Kelompok kecil dan kelompok besar. Mendengarkan pendapat satu sama lain.

Matematika hanya beberapa anak yang berperan. Matematika butuh konsentrasi dibanding mata pelajaran yang lain. Model yang belum bisa diterapkan kelas 3. Belajar dengan media alam. Belajar di lapangan, mengenal jenis2 daun di sekitar sekolah. Di sekolah banyak kebun yang bisa diamati secara 
Pembelajaran Kolaboratif Sekolah....(Ignasius Heri S.W., Ignatius Putera S., Antonius Singgih S.)

langsung. Kendala di anak. Kemampuan mereka dibatasi orang tua. Orang tua kurang support. Jam 11-12 pembelajaran di luar kelas. Pembelajaran luar kelas. Orang tua khawatir kepanasan. Pagi hari konsentrasi masih bagus. Jam siang hari kurang disupport orang tua. Masalah yang sangat umum, anak yang sangat jahil, tidak bisa bekerja sama. Sudah punya kelompok. Antusias, menyampaikan pendapat. Ada sangsi atau reward.

Kode: dibagi jadi beberapa kelompok, mendengarkan pendapat satu sama lain, dibatasi orang tua, kurang disupport orang tua

Kategori: partisipasi, peran, intervensi

4) Partisipan-4: Ibu "M"

Model-model pembelajaran talking stake dan jigsaw. Pembagian tugas berkelompok. Kelompok Heterogen. Perbedaan siswa bisa saling menutupi. Anggota kelompok yang lain dapat membantu. Guru memberikan icebreaking. Memberi kesegaran. Agar siswa tdk jenuh dalam proses pembelajaran. Bagaimana nilai efektifitas model pembelajaran yang diterapkan. Bekerjasama seharian di kelas. Kelas rendah belum mampu metode kelompok atau diskusi. Kelas tinggi sudah mampu kerjasama dalam kelompok.

Berkaitan dengan nilai efektifitas model pembelajaran yang diterapkan balik lagi ke fungsi pembelajarannya. Berusaha menarik dan tidak monoton. Efektif atau tidaknya bergantung guru dalam menerapkan model pembelajaran itu sendiri. Tidak menutup kemungkinan guru menerapkan model pembelajaran lain. Kendalanya siswa tidak paham dengan model pembelajaran yang kita gunakan. Kadang juga tidak terbiasa menggunakan model pembelajaran, jadi materi tidak disampaikan. Itu dari sisi guru ya.

Kode: anggota kelompok yang lain dapat membantu, icebreaking, berusaha menarik dan tidak monoton

Kategori: partisipasi, intervensi

5) Partisipan-5: Pak "S"

Kalau saya belajar sebelum pandemi. Saya mengajar anak2 dengan cara bermain. Bermain keluar kelas atau di dalam kelas. Berkelompok. Misalnya matematika. Dua kelompok. Didalam kelompok ada kelompok lagi. Satu 
kelompok pegang soal, kelompok lain pegang jawaban. Mereka saling mencari teman yang sesuai dengan jawaban mereka, lalu dipindah lagi. Yang soal pegang soal. Merubah kelompok siswa. Saya selalu bagi tidak dalam kelompok yang sama di tiap pembelajaran. Ada yang tidak akur atau yang sebelumnya bertengkar akan saya gabung. Kerjasama walaupun dengan orang yang tidak akur. Reaksi. Mereka senang kalau diajak bermain. Ada 1-2 orang yang terlalu pendiam. Tidak bisa mengekspresikan itu senang atau sedih. Tapi jika diajak bermain mereka selalu aktif. Secara keseluruhan reaksi mereka lebih senang kalau diajak bermain daripada mencatat atau latihan di kelas.

Kode: berkelompok, merubah kelompok siswa, akan saya gabung

Kategori: pembagian, intervensi

Tabulasi deskripsi kode dan kategori narasi partisipan (Tabel-1) dilakukan sehingga data kualitatif yang diperoleh dari lapangan dapat dipersiapkan untuk dihubungkan dengan teori.

Tabel 1. Tabulasi Deskripsi Kode dan Kategori Narasi Partisipan

\begin{tabular}{|c|c|c|c|c|}
\hline No. & Partisipan & Kode & Kategori & Deskripsi \\
\hline 1 & Ibu "X" & $\begin{array}{l}\text { kelas bawah - } \\
\text { kelas atas, } \\
\text { contoh- } \\
\text { contoh benda } \\
\text { yang } \\
\text { kongkrit, } \\
\text { memegang } \\
\text { tangan }\end{array}$ & $\begin{array}{l}\text { pembagian, } \\
\text { intervensi }\end{array}$ & $\begin{array}{l}\text { Pengalaman Ibu "X" dalam } \\
\text { pembelajaran kolaboratif } \\
\text { menyebutkan perlunya } \\
\text { pembagian yang disebut } \\
\text { sebagai pemisahan (division) } \\
\text { menurut tingkatan } \\
\text { kompetensi. Kata "kelas } \\
\text { bawah - kelas atas" dipilih } \\
\text { oleh partisipan sekaligus } \\
\text { menekankan adanya } \\
\text { pemisahan yang jelas. } \\
\text { Intervensi juga dilakukan } \\
\text { melalui dua cara: Pertama, } \\
\text { secara langsung dengan } \\
\text { "memegang tangan siswa". } \\
\text { Kedua, secara tidak } \\
\text { langsung dengan } \\
\text { memberikan materi } \\
\text { pembelajaran yang berupa } \\
\text { obyek nyata. }\end{array}$ \\
\hline
\end{tabular}




\begin{tabular}{|c|c|c|c|c|}
\hline No. & Partisipan & Kode & Kategori & Deskripsi \\
\hline 2 & Ibu "Y" & $\begin{array}{l}\text { waktu tersita, } \\
\text { membagi } \\
\text { kelompok, } \\
\text { pembagian } \\
\text { laki-laki - } \\
\text { perempuan, } \\
\text { mereka } \\
\text { sendiri yang } \\
\text { menentukan }\end{array}$ & $\begin{array}{l}\text { pembagian, } \\
\text { partisipasi, } \\
\text { intervensi }\end{array}$ & $\begin{array}{l}\text { Pengalaman Ibu "Y" dalam } \\
\text { pembelajaran kolaboratif } \\
\text { menyebutkan tentang } \\
\text { sumber daya waktu yang } \\
\text { dipakai untuk membuat } \\
\text { kelompok. Terdapat } \\
\text { pembagian menurut gender, } \\
\text { dan intervensi guru untuk } \\
\text { menentukan pembentukan } \\
\text { kelompok. Dengan } \\
\text { menggunakan cara yang } \\
\text { lebih terbuka (siswa boleh } \\
\text { memilih teman dalam } \\
\text { kelompok). Cara ini } \\
\text { memotivasi tingkat } \\
\text { partisipasi. }\end{array}$ \\
\hline 3 & Ibu "Z" & $\begin{array}{l}\text { Dibagi jadi } \\
\text { beberapa } \\
\text { kelompok, } \\
\text { mendengarka } \\
\text { n pendapat } \\
\text { satu sama } \\
\text { lain, dibatasi } \\
\text { orang tua, } \\
\text { kurang } \\
\text { disupport } \\
\text { orang tua }\end{array}$ & $\begin{array}{l}\text { partisipasi, } \\
\text { peran, } \\
\text { intervensi }\end{array}$ & $\begin{array}{l}\text { Pengalaman Ibu "Z" dalam } \\
\text { pembelajaran kolaboratif } \\
\text { menyebutkan tentang } \\
\text { pembagian kelompok. } \\
\text { Terdapat pembentukan } \\
\text { peran sekaligus partisipasi } \\
\text { untuk menyampaikan dan } \\
\text { mendengarkan pendapat. } \\
\text { Kata "dibatasi orang tua" } \\
\text { mengindikasi sebuah } \\
\text { intervensi }\end{array}$ \\
\hline 4 & Ibu "M" & $\begin{array}{l}\text { Anggota } \\
\text { kelompok } \\
\text { yang lain } \\
\text { dapat } \\
\text { membantu, } \\
\text { icebreaking, } \\
\text { berusaha } \\
\text { menarik dan } \\
\text { tidak } \\
\text { monoton }\end{array}$ & $\begin{array}{l}\text { partisipasi, } \\
\text { intervensi }\end{array}$ & $\begin{array}{l}\text { Pengalaman Ibu "M" dalam } \\
\text { pembelajaran kolaboratif } \\
\text { secara tidak langsung } \\
\text { menyebutkan "partisipasi" } \\
\text { dalam kerja kelompok. Kata } \\
\text { "anggota kelompok yang } \\
\text { lain dapat membantu" } \\
\text { merupakan indikasi } \\
\text { diperlukannya partisipasi. } \\
\text { Kata "icebreaking" } \\
\text { merupakan bentuk intervensi } \\
\text { sehingga aktivitas kelompok }\end{array}$ \\
\hline
\end{tabular}




\begin{tabular}{|c|c|c|c|c|}
\hline No. & Partisipan & Kode & Kategori & Deskripsi \\
\hline & & & & $\begin{array}{l}\text { dapat dipersepsi sebagai } \\
\text { "menyenangkan". Intervensi } \\
\text { juga dilakukan dalam bentuk } \\
\text { upaya motivasional untuk } \\
\text { menghindari kebosanan dan } \\
\text { kejenuhan. }\end{array}$ \\
\hline 5 & Pak "S" & $\begin{array}{l}\text { berkelompok, } \\
\text { merubah } \\
\text { kelompok } \\
\text { siswa, akan } \\
\text { saya gabung }\end{array}$ & $\begin{array}{l}\text { pembagian, } \\
\text { intervensi }\end{array}$ & $\begin{array}{l}\text { Pengalaman Pak "S" dalam } \\
\text { pembelajaran kolaboratif } \\
\text { menyebutkan kata } \\
\text { "berkelompok". Kelompok } \\
\text { ini adalah sekumpulan } \\
\text { individu yang saling } \\
\text { bekerjasama. Intervensi } \\
\text { dilakukan dalam batasan } \\
\text { merubah keanggotaan dalam } \\
\text { kelompok dengan komposisi } \\
\text { yang beragam }\end{array}$ \\
\hline
\end{tabular}

Pengalaman Ibu "X" dalam pembelajaran kolaboratif menyebutkan perlunya pembagian yang disebut sebagai pemisahan (division) menurut tingkatan kompetensi. Kata "kelas bawah - kelas atas" dipilih oleh partisipan sekaligus menekankan adanya pemisahan yang jelas. Intervensi juga dilakukan melalui dua cara: Pertama, secara langsung dengan "memegang tangan siswa". Kedua, secara tidak langsung dengan memberikan materi pembelajaran yang berupa obyek nyata. (Deskripsi Kode dan Kategori Narasi Partisipan \#1)

Melalui Deskripsi Kode dan Kategori Narasi Partisipan \#1 dapat ditunjukkan pembagian menggunakan kriteria tertentu untuk memudahkan proses penerapan pembelajaran kolaboratif. Pembagian seperti ini merupakan bentuk intervensi atau keterlibatan orang dewasa (Burkhalter, 1995) dengan melihat kapasitas partisipasi dan keterlibatan anggota kelompok. Intervensi ini menentukan dinamika yang terjadi dalam sebuah kelompok. Kelompok dengan tingkat intensitas interaksi yang dinamis mengarah kepada partisipasi dan keterlibatan yang tinggi. Situasi ini juga sekaligus menghubungkan proses sosial dan mental (Gindis, 1999) yang menjadi karakteristik model Vygotsky. 
Pembelajaran Kolaboratif Sekolah....(Ignasius Heri S.W., Ignatius Putera S., Antonius Singgih S.)

Individu melalui partisipasi dan keterlibatannya menjalani proses berbagibergabung (shared-joint process) dimana segala ide ditransaksikan dan dipertukarkan. Sebuah keterikatan transaktif (Damon \& Phelps, 1989) dikatakan mengarah kepada pertumbuhan (Dillenbourg, 1999) karena individu dikondisikan untuk mengkomunikasikan sekaligus mengkonfirmasi ide dan gagasannya. Situasi ini membawa kepada pembelajaran sosial dengan melibatkan teman2 sebaya dalam proses pembelajaran (Vygotsky, 1962).

Dalam konteks pembelajaran kolaboratif sekolah dasar ditemukan intervensi orang dewasa (Vygotsky, 1962) yang dilakukan secara langsung. Intervensi ini menunjukkan sebuah upaya memotivasi sekaligus kemampuan mengarahkan individu kepada sebuah tantangan sebagaimana yang dilakukan oleh Partisipan-1. Individu juga difasilitasi di dalam zona perkembangan potensialnya (Zone of Proximal Development) melalui obyek-objek nyata yang mudah dipahami menurut ukuran kemampuan kognitif mereka.

Pengalaman Ibu "Y" dalam pembelajaran kolaboratif menyebutkan tentang sumber daya waktu yang dipakai untuk membuat kelompok. Terdapat pembagian menurut gender, dan intervensi guru untuk menentukan pembentukan kelompok. Dengan menggunakan cara yang lebih terbuka (siswa boleh memilih teman dalam kelompok). Cara ini memotivasi tingkat partisipasi. (Deskripsi Kode dan Kategori Narasi Partisipan \# 2)

Deskripsi Kode dan Kategori Narasi Partisipan \# 2 melengkapi referensi mengenai intervensi yang dilakukan menggunakan kriteria gender. Individu belum mencapai usia kematangan dalam membuat sebuah pilihan. Ini kemudian menempatkan fasilitator orang dewasa (Vygotsky, 1962) melakukan intervensi dengan menggunakan kriteria dasar yang memudahkan individu masuk dalam ikatan pertukaran atau transaksi ide dan gagasan. Terdapat pertimbangan kenyamanan pembelajaran (misalnya dalam menerapkan pola yang lebih demokratis dimana individu bebas memilih anggota kelompok) diikuti dengan aktivitas tertentu yang memiliki tingkat kesulitan berjenjang (Burkhalter, 1995) untuk mengarahkan individu pada tingkatan berpikir yang lebih tinggi (Vygosky, 1962). Fasilitator sebagai pihak yang melakukan intervensi menggunakan sumber 
daya waktu (time resources) dalam proses pembuatan kelompok. Dinamika pembuatan kelompok mampu berkontribusi kepada target pembelajaran yang mentranformasikan permasalahan menjadi kesempatan untuk mencapai tingkatan berpikir yang lebih tinggi (Vygotsyk, 1962).

Pengalaman Ibu "Z" dalam pembelajaran kolaboratif menyebutkan tentang pembagian kelompok. Terdapat pembentukan peran sekaligus partisipasi untuk menyampaikan dan mendengarkan pendapat. Kata "dibatasi orang tua" mengindikasi sebuah intervensi. (Deskripsi Kode dan Kategori Narasi Partisipan \# 3)

Deskripsi Kode dan Kategori Narasi Partisipan \#3 menekankan pada pembagian kelompok dan peran ganda (dual role). Di satu sisi individu dikondisikan untuk menyampaikan ide dan gagasan terdalamnya, di sisi lainnya individu mampu menjadi sarana untuk mendengarkan segala ide dan gagasan orang lain. Peran ini sekaligus kepakaran yang dibagikan (shared expertise), menjadi mekanisme dalam mencapai pertumbuhan (Dillenbourg, 1999). Dalam kondisi tertentu diperlukan intervensi eksternal keluarga. Individu secara emosional terikat oleh factor-faktor di luar ruang kelas (classroom). Ini dilakukan melalui pertimbangan tingkat ketergantungan individu yang masih tinggi terhadap individu lain yang lebih dewasa (Vygotsky, 1962).

Pengalaman Ibu "M" dalam pembelajaran kolaboratif secara tidak langsung menyebutkan "partisipasi" dalam kerja kelompok. Kata "anggota kelompok yang lain dapat membantu" merupakan indikasi diperlukannya partisipasi. Kata "icebreaking" merupakan bentuk intervensi sehingga aktivitas kelompok dapat dipersepsi sebagai "menyenangkan". Intervensi juga dilakukan dalam bentuk upaya motivasional untuk menghindari kebosanan dan kejenuhan. (Deskripsi Kode dan Kategori Narasi Partisipan \#4)

Pengalaman Pak "S" dalam pembelajaran kolaboratif menyebutkan kata "berkelompok". Kelompok ini adalah sekumpulan individu yang saling bekerjasama. Intervensi dilakukan dalam batasan merubah keanggotaan dalam kelompok dengan komposisi yang beragam. (Deskripsi Kode dan Kategori Narasi Partisipan \#5) 
Pembelajaran Kolaboratif Sekolah....(Ignasius Heri S.W., Ignatius Putera S., Antonius Singgih S.)

Deskripsi Kode dan Kategori Narasi Partisipan \# 4 dan Partisipan \# 5 menjelaskan upaya2 mengelola kenyamanan pembelajaran dimana individu saling mengenal satu sama lain. Intervensi orang dewasa sebagai penghubung proses sosial dan mental (Gindis, 1999) dengan menghadapkan individu sebagai bagian dari individu yang lain. Relasi interaktif dalam kelompok menghadapkan individu untuk saling mengenal dan dikenal. Ini merupakan langkah awal sebelum proses pembelajaran kolaboratif dilakukan. Pertukaran dalam kerangka interaksi kerjasama terjadi ketika individu memahami peran dan partisipasinya sekaligus pihak2 yang terlibat di dalamnya. Individu yang mengenal satu sama lain adalah manifestasi interaksi sosial dalam ruang pembelajaran (Totten, Sills, Digby \& Russ, 1991).

\section{SIMPULAN}

Pembelajaran kolaboratif memiliki peran sentral menempatkan individu yang kontributif dan partisipatif melalui keterlibatannya secara aktif dalam aktivitas pembelajaran berbasis kelompok. Individu bersama dengan individu yang lain menunjukkan eksistensinya dalam sebuah kelompok, dibantu fasilitator, melakukan berbagai kegiatan berbagi peran dan partisipasi. Dalam konteks sekolah dasar intervensi fasilitator baik secara langsung maupun tidak langsung memandu proses kegiatan kelompok. Intervensi juga bertujuan menjaga iklim kenyamanan proses pembelajaran, yakni sebuah kondisi dimana individu dapat memberdayakan kemampuan kognitifnya untuk menyerap hal-hal baru, sekaligus mengembangkan kapasitas pembelajarannya secara maksimal.

Model Vygotsky adalah adopsi pendekatan pembelajaran sosial, sebuah paham mengenai "orang lain turut berperan" (others do matter). Adopsi model Vygotsky menempatkan keseluruhan individu dalam sebuah kelompok memiliki porsi yang sama untuk berkontribusi terhadap kemajuan. Melalui mekanisme intervensi fasilitator, masing2 pihak mendayagunakan aset bagian (portion) anggota kelompok untuk berbagi dan bekerjasama. 


\section{DAFTAR PUSTAKA}

Blair, E. (2015) A Reflexive Exploration of Two Qualitative Data Coding Techniques. Journal of Methods and Measurement in the Social Sciences Vol. 6, No. 1, 14-29, 2015

Burkhalter, N. (1995) A Vygotsky-based curriculum for teaching persuasive writing in the elementary grades. Language Arts Vol. 72 No. 3 pp. 192-199. National Council of Teachers of English

Cohen, E.G. (1994) Restructuring the classroom: conditions for productive small groups. Review of Educational Research, 64, 1-35

Damon, W. \& Phelps, E. (1989) Critical distinction among three approaches to peer education. International Journal of Educational Research, 58, 9-19

Dillenbourg, P. (1999) What do you mean by 'collaborative learning'? In P. Dillenbourg (Ed.), Collaborative learning: cognitive and computational approaches (pp. 1-19). Oxford, UK: Elsevier

Gindis, B. (1999) Vygotsky's Vision. Reshaping the Practice of Special Education for the 21st Century. Remedial and Special Education Vol. 20 No. 6 November/December pp. 333-340

Johnson, R. T., \& Johnson, D. W. (1986). Action research: Cooperative learning in the science classroom. Science and Children , 24, 31-32.

Summers, J.J. (2006) Effects of collaborative learning in math on sixth graders' individual goal orientations from a socioconstructivist perspective. The Elementary School Journal, 106, 273-290

Totten, S., Sills, T., Digby, A., \& Russ, P. (1991). Cooperative learning: A guide to research. New York: Garland.

Vygotsky, L.S. (1962) Thought and Language, edited and translated by Eugenia Hanfman and Gertrude Vakar. Cambridge, MA: the M I T Press. 